ISSN : 2550-0198

\title{
PERENCANAAN PENGELOLAAN REKAM MEDIS SESUAI DENGAN STANDAR PEDOMAN PENYELENGGARAAN DAN PROSEDUR REKAM MEDIS DIKLINIK PRATAMA KOTA PEKANBARU
}

\author{
Henny Maria Ulfa*, Haryani Octaria, Tri Purnama Sari \\ STIKes Hang Tuah Pekanbaru \\ *Email :Hennyulfa84@gmail.com
}

\begin{abstract}
Abstrak
Rekam Medis (RM) mempunyai tujuan untuk melindungi pasien dan dokter yang berkaitan dengan hukum serta menunjang tercapainya tertib administrasi dalam rangka upaya peningkatan pelayanan kesehatan di rumah sakit. Pimpinan bertanggung jawab menyediakan sarana unit rekam medis yang meliputi ruang, peralatan dan tenaga yang memadai sehingga pengelolaan rekam medis dapat bejalan dengan baik. Klinik Pratama Rumah Zakat dan Indo Sehat sudah melaksanakan rekam medis secara manual, namun untuk pengelolaanrekam medis belum tidak sesuai dengan standar yang telah ditentukan oleh Pedoman Penyelenggaraan dan Prosedur Rekam Medis seperti formulir rawat jalan, map, dan rak penyimpanan. Oleh karena itu dengan dilakukanya Ipteks bagi masyarakat ini dapat memperbaiki pengelolaan rekan medis di dua klinik pratama tersebut.
\end{abstract}

Kata Kunci: Klinik Pratama, Pengelolaan Rekam medis, Standar Rekam Medis

\section{PENDAHULUAN}

Menurut Undang-Undang Praktik Kedokteran Nomor 29 Tahun 2004 mewajibkan kepada dokter sebagai pemberi layanan kesehatan untukmembuat rekam medis, begitu pula atas tindakan yang dilakukan harus mendapat persetujuan dari pasien. Petugas rekam medis yang ada di Klinik Pratama Rumah Zakat berjumlah 1 tamatan D3 RMIK orang, sedangkan untuk Klinik Pratama Indo Sehat belum memiliki petugas tamatan D3 RMIK. Di wilayah Klinik Pratama Rumah Zakat jumlah kunjungan pada 1 bulan yaitu 760 orang, dengan total pasien baru rawat jalan dalam 1 tahun berjumlah 200 dan pasien lama 150 jika dihitung jumlah berkas rekam medis dalam 2 tahun berjumlah 421,9 berkas sehingga Klinik Pratama Rumah Zakat memerlukan penambahan rak sebanyak 1 rak, sedangkan untuk Klinik Pratama Indo Sehat pada 1 bulan yaitu 78 , dengan total pasien rawat jalan baru berjumlah 300 orang dalam 1 tahun dan pasien lama berjumlah 200 orang jika dihitung jumlah berkas rekam medis dalam 5 tahun berjumlah 1602,7 berkas sehingga Klinik Pratama Rumah Zakat memerlukan penambahan rak sebanyak 1 rak, pengelolaan rekam medis di 2 klinik pratama yang ada di kota Pekanbaru belum terlaksana secara optimal, sehingga untuk formulir rawat jalan, map, dan rak penyimpanan tidak sesuai dengan standar yang telah ditentukan oleh 
Pedoman Penyelenggaraan dan Prosedur Rekam Medis.

Klinik Pratama adalah bagian yang penting di bidang kesehatan dan berperan dalam menunjang kelangsungan hidup masyarakat agar hidup sehat dan sejahtera. Klinik Pratama mempunyai beberapa ruang baik untuk pengobatan, pelayanan, informasi, dan bagian rekam medis. Permenkes Nomor 269 Tahun 2008 menyebutkan bahwa setiap sarana pelayanan kesehatan wajib menyelenggarakan rekam medis. Rekam Medis (RM) adalah berkas yang berisikan catatan dan dokumen tentang identitas pasien, pemeriksaan, pengobatan, tindakan dan pelayanan lain kepada pasien pada sarana pelayanan kesehatan. Rekam medis mempunyai tujuan untuk melindungi pasien dan dokter yang berkaitan dengan hukum serta menunjang tercapainya tertib administrasi dalam rangka upaya peningkatan pelayanan kesehatan di rumah sakit.Pimpinan bertanggung jawab menyediakan sarana unit rekam medis yang meliputi ruang, peralatan dan tenaga yang memadai sehingga pengelolaan rekam medis dapat bejalan dengan baik.

Berbeda dengan apa yang telah penulis kemukakan di atas adalah bahwa pada pelaksanaan rekam medis, penyedia pelayanan kesehatan tidak menyadari sepenuhnya manfaat dan kegunaan rekam medis, baik pada sarana kesehatan maupun pada praktik perorangan, akibatnya rekam medis sering dibuat tidak lengkap, tidak jelas dan tidak tepat waktu begitu jugapegelolaan pada bagian rekam medis itu sendiri dan sesuai dengan Permenkes Nomor 269 Tahun 2008 Rekam medis dapat dipakai sebagai alat bukti dokumen dalam perkara hukum diamana untuk pembuatan rekam medis harus memenuhi unsur minimal seperti yang disyaratkan yaitu; data umum, data medis dan data sosial, cara penyelenggaraan rekam medis, pemusnahan, penyimpanan, pembinaan dan pengawasan sehingga dapat berjalan denganbaik.

Mitra dalam kegiatan pengabdian masyarakat ini adalah Klinik Pratama yang telah melaksanakan rekam medis.formulir rekam medis dan map yang telah ada belum memenuhi harapan, tenaga perekam medis dan fasilitas yang belum memenuhi harapan terutama rak penyimpanan serta tidak adanya pengawasan yang dilakukan dinas kesehatan terkait pelaksanaan Permenkes No.269 Tahun 2008.Menurut Normijan (2013)menyatakan bahwa untuk tempat penyimpanan 4 orang $(36,4 \%)$ responden mengatakan tidak memenuhi syarat, 4 orang $(36,4 \%)$ mengatakan sebagian memenuhi syarat dan 3 orang responden $(27,2$ \%) mengatakan memenuhi syarat.

Dalam memberikan pelayanan kedokteran atau kesehatan, terutama yang dilakukan oleh dokter dirumah sakit atau praktik mandiri, peran rekam medis sangatlah penting dan melekat pada kegiatan tersebut. Oleh karena itu ada ungkapan bahwa rekam medis adalah orang ketiga pada saat dokter menerima pasien. Hal ini memungkinkan karena rekam medis merupakan catatan yang berguna untuk mengingatkan kembali dokter akan keadaan pasien, hasil pemeriksaan serta tindakan yang diberikan dokter pada waktuitu. 
ISSN : 2550-0198

Berdasarkan wawancara dengan petugas rekam medis yang ada di Klinik Pratama Rumah Zakat dan Indo Sehat tentang pengelolaan rekam medis masih menggunakan sistem manual, ditemukan masih banyak yang kurangnya pengetahuan tentang pentingnya rekam medis baik itu standar formulir pasien rawat jalan, map dan rak penyimpanan dan bagaiamana

cara

mengoptimalisasikan pelaksanaan rekam medis sesuai dengan Pedoman Penyelenggaraan dan Prosedur Rekam Medis, Hal ini terlihat pada gambar berikut:

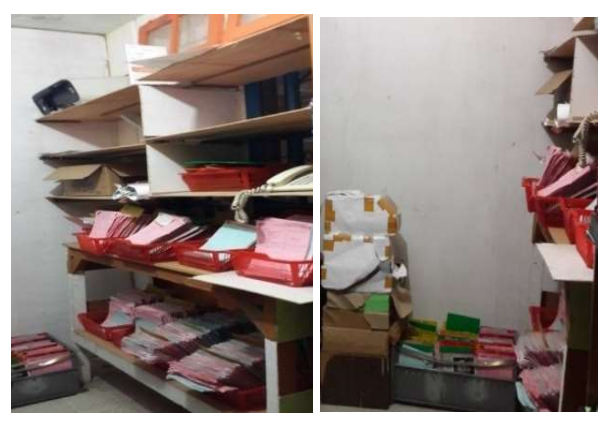

Gambar 1.Foto rak penyimpanan rekam medis di klinik pratama rumah zakat

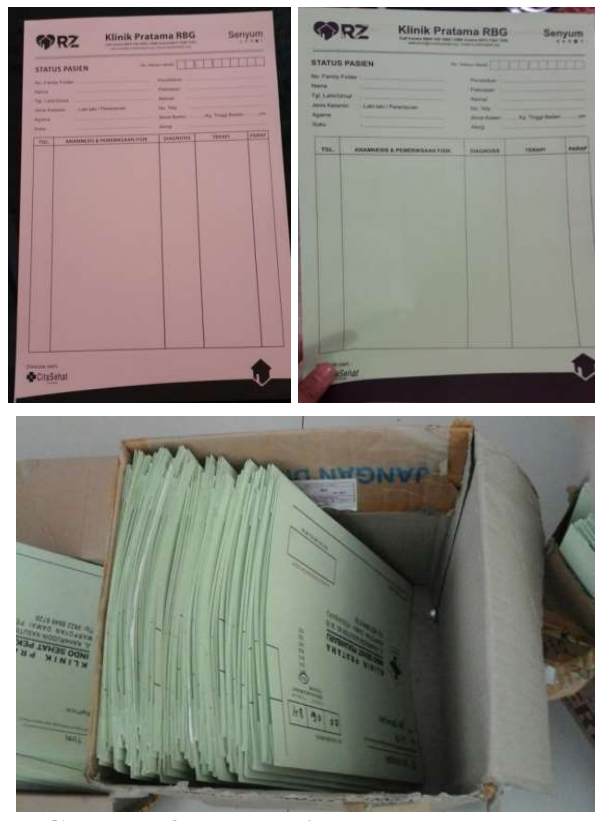

Gambar 2. Formulir dan map rekam medis di klinik pratama
Momok menakutkan tentang sanksi dan pidana terhadap fasilitas pelayanan kesahatan yang belum terlaksananya rekam medis sesuai dengan Undang-Undang Praktik Kedokteran Nomor 29 Tahun 2004 ditujukan untuk melindungi pasien dan dokter sehinga dapat terlindungi secara hukum.Keberadaan klinik yang ada di Pekanbaru beresiko terhadap tidak terlaksananya pengelolaan rekam medis sesuai standar seperti formulir pasien rawat jalan, map dan rak penyimpanan sebagai salah satu indikator mutu pelayanan kesehatan menjadi unsur yang akan sangat berpengaruh dalam peta masalah kesehatan baik tingkat kecamatan, kota bahkan mungkin sampai tingkat propinsi.

Sebagai mitra dalam pelaksanaan IbM ini adalah Klinik Pratama sekota Madya Pekanbaru yang telah melaksanakan rekam medis yaitu Klinik Prtama Rumah Zakat dan Indo Sehat. Berdasarkan analisis situasi dapat terindetifikasi beberapa permasalahan mitra, yaitu:

a. Berdasarkan hasil wawancara dengan Klinik Pratama Rumah Zakat dan Indo Sehat sebagai mitra tentang pengelolaan rekam medis, mitra mengatakan pengelolaan rekam medis belum sesuai dengan standar yang telah ditentukan, seperti halnya padapendaftaran masih menggunakan sistem manual, formulir pasien rawat jalan dan map tidak sesuai dengan ukuran, isi, dan ketebalannya, begitu juga untuk rak penyimpanan mitra menyatakan masih kekurangan dan hanya menggunakan lemari bekas 
ISSN : 2550-0198

obat dan untuk penyimpanan hanya ditumpuk sehingga mempersulit petugas dalam memberikan pelayanan kepada pasien

b. Berdasarkan hasil survey di Klinik Pratama Rumah Zakat dan Indo Sehat di kota Pekanbaru, terbatasnya sarana dan prasarana dalam mengoptimalisasikan pengelolaan rekam medis, serta Pedoman Penyelenggaraan dan
Prosedur Rekam Medis yang tidak ada baik itu untuk formulir pendaftaran, map, maupun rak penyimpanan dan tidak adanya software pendaftaran dalam memberikan pelayanan.

\section{PEMECAHAN MASALAH}

Berdasarkan analisa situasi masalah diatas maka, diajukan kerangka pemecahan masalah seperti yang dibawah ini :

\section{Permasalahan \\ 1. Formulir rawat jalan tidak sesuai \\ 2. Map rekam medis tidak sesuai \\ 3. Belum menggunakan rak penyimpanan \\ 4. Tidak adanya Softwere untuk bagian pendaftaran}

Solusi :

1. Penyuluhan pengelolaan rekam medis

2. Pelatihan pengelolaan rekam medis

3. Pelatihan penggunaan softwere

4. Perbaikan pengelolaan rekam medis (formulir, map dan rak penyimpanan)

Gambar 3: Kerangka pemecahan masalah

\section{METODE PELAKSANAAN}

Pelaksanaan kegiatan ini dilakukan didua klinik pratama yang ada di kota pekanbaru yaitu klinik pratama rumah zakat yang berlokasi di jalan nenas No 11 Sukajadi
Pekanbaru dan klinik pratama indo sehat yang berlokasi di jalan Kharuddin Nasution No 38-39 Marpoyan damai Pekanbaru, yang berlangsung pada bulan Januari 2017. 
ISSN : 2550-0198

Metode pendekatan yang digunakan adalah metode pendekatan komunitas dan pendekatan kepada kepala klinik pratama. Pendekatan komunitas diwujudkan dalam bentuk penyuluhan kepada petugas rekam medis. Sedangkan pendekatan kepada kepala klinik pratama dengan penekanan pada kebijakan pengelolaan rekam medis secara baik dan benar agar terlaksananya pelayanan rekam medis yang optimal.

Rancangan mekanisme
pelaksanaan kegiatan IbM ini
dilakukan dengan mengadopsi
langkah-langkah action researchi
yang terdiri dari 4 (empat) tahapan,
yaitu: perencanaan, tindakan,
observasi dan evaluasi serta refleksi.
Kegiatan-kegiatan atau aktivitas-
aktivitas dari masing-masing tahapan
adalah sebagai berikut:

\section{Tahap perencanaan}

a. Langkah awal jalannya kegiatan pengabdian pada masyarakat ini adalah mengurus surat pengantar dan surat zin kegiatan pengabdian masyarakat.

b. Melakukan pengumpulan data

c. Melakukan perumusan masalah

d. Menentukan prioritas penyelesaian masalah

e. Menyusun kerangka penyelesaian masalah berdasarkan masalah yang dipilih

f. Mempersiapkan materi penyuluhan dan format pelatihan rekam medis

g. Mempersiapkan kelengkapan peralatan penyuluhan seperti alat tulis, leaflet, laptop, infokus

h. Mempersiapkan

kelengkapan peralatan untuk pengukuran rak rekam medis dan desain formulir

i. Menjelaskan tujuan kegiatan pengabdian pada masyarakat kepada mitra, Petugas Rekam Medis dan kepala Klinik Pratama.

2. Tahap tindakan pelaksanaan

a. Meminta kesediaan mitra untuk mengikuti kegiatan pengabdian kepada masyarakat

b. Memberikan penjelasan tentang kegiatan yang akan dilaksanakan

c. Melaksanakan Iptek Bagi Masyarakat

Tidak sesuainya pengelolaan rekam medis dengan pedoman pengelolaan penyelenggaraan dan prosedur rekam medis merupakandasar berfikir kami untuk mewujudkan program-program yang kami lakukan dalam menyelesaikan masalah kelompok mitra ini. Program yang akan kami lakukan adalah:

1. Penyuluhan

Penyuluhan kepada kepala klinik pratama dan petugas rekam medis dalam bentuk memberikan pengetahuan kepada petugas rekam medis dan kepala klinik pratma tentang desain formulir, indeks penyakit, pelaporan dan softwere rekam medis.

2. Pelatihan petugas rekam medis dan Pimpinan klinik

Pelaksanaan pelatihan kepada petugas rekam medis dan pimpinan mengenai pengelolaan rekam medis . 
ISSN : 2550-0198

Dalam pelaksanaan program kami mengharapkan semua petugas rekam medis akan termotivasi untuk mengikuti pelatihan yang kami adakan dengan sepenuh hati dan para pemilik klinik pratama mendukung dalam kegiatan ini dan dapat menerima kami untuk melakukan perubahan dalam pengelolaan rekam medis. Langkah ke arah itu dimulai dari pendekatan kepada kepala klinik pratama yang sangat menentukan penerimaan perubahan pengelolaan rekam medis terhadap kegiatan yang kami lakukan ini.

\section{Observasi dan evaluasi}

Observasi dilakukan terhadap proses pembinaan kepada petugas rekam medis dalam memberikan pelatihan dan penyuluhan tentang rekam medis. Beberapa hal yang diobservasi adalah kendala-kendala, kekurangan-kekurangan dan kelemahan-kelemahan yang muncul dalam proses pelatihan dan penyuluhan.

4. Refleksi

Refleksi dilakukan terhadap kegiatan yang telah dilaksanakan. Hal ini dilakukan semata-mata untuk mengetahui kekurangan-kekurangan atau kelebihan-kelebihan terhadap kegiatan yang telah dilakukan dalam rangka untuk menetapkan rekomendasi terhadap keberlangsungan atau pegembangan kegiatan-kegiatan berikutnya.

\section{HASIL YANG DICAPAI}

Pengabdian IbM Perencanaan Pengelolaan Rekam Medis Sesuai Dengan Standar Pedoman
Penyelenggaraan Dan Prosedur Rekam Medis Diklinik Pratama Kota Pekanbaru ini telah dilaksanakan sejak bulan Maret 2016. Adapun kegiatan-kegiatan yang telah dilakukan adalah sebagai berikut:

1. Peninjauan tempat untuk kegiatan penyuluhan kepada mitra pengabdian yang berlokasi di klinik pratama rumah zakat yang bertempat dijalan Nenas dan klinik pratama indosehat yang bertempat dijalan Kaharudin Nasution, No. 36-39.

2. Melakukan penyuluhan tentang konsep dasar rekam medis dan pelatihan tentang registrasi, desain map, formulir, outguate, dan tracer yang dilakukan oleh tim pengabdian

3. Peninjauan tempat penyuluhan software kepada kedua mitra pengabdian

4. Identifikasi alat-alat yang dibutuhkan oleh mitra pengabdian

5. Mempersiapkan kegiatan penyuluhan kepada dua mitra pengabdian tentang Pengelolaan Rekam Medis Sesuai Dengan Standar Pedoman Penyelenggaraan Dan Prosedur Rekam Medis Diklinik Pratama Kota Pekanbaru

6. Melaksanakan kegiatan penyuluhan dan pelatihan Pengelolaan Rekam Medis Sesuai Dengan Standar Pedoman Penyelenggaraan Dan Prosedur Rekam Medis Diklinik Pratama Kota Pekanbaru serta pelaksanaan pelatihaan pengelolaan rekam medis dan pelatihan SIMRS oleh IT:

1. Penyuluhan tentang pengelolaan rekam medis 
ISSN : 2550-0198

dengan pelatihan pengelolaan rekam medis oleh Henny Maria Ulfa, A. Md. PK, SKM, M. Kes

2. Penyuluhan tentang registrasi, desain map, formulir, outguate, dan tracer rekam medis oleh Haryani Octaria, A. Md. PK, SKM, M. Kes

3. Pemberian pelatihan pengelolaan rekam medis kepada petugas rekam medis oleh tim penyuluhan

4. Pemberian pelatihan SIMRS kepada petugas rekam medis oleh tim penyuluhan dan IT

5. Pemberian alat-alat dan rak rekam medis yang diperlukan untuk kegiatan pengabdian

6. Pelaksanaan pengelolaan rekam medis di dua tempat oleh petugas rekam medis yang telah dilatih

7. Dari hasil peninjauan terhadap pengelolaan rekam medis di dua klinik pratama kota Pekanbaru, didapat bahwa petugas rekam medis masih belum memahami bagaimana pengelolaan rekam medis di klinik yang sesuai dengan standar departemen kesehatan (DepKes).

8. Setelah dilakukan peninjauan tersebut kami melakukan pengecekan terhadap formulir rawat jalan, map, rak rekam medis, dan SIMRS di dua klinik pratama tersebut, ditemukannya formulir untuk identitas pasien, formulir rawat jalan, map rekam medis belum sesuai standar dan ketentuan DepKes, rak rekam medis sudah ada namun belum mencukupi, belum terdapatnya tracer dan outguet, Serta SIMRS yang belum berjalan dengan baik, Karna masih banyaknya alat-alat rekam medis yang belum sesuai dengan standar DepKes, kami memberikan kepada kedua klinik pratama tersebut alat-alat rekam medis yang nanti akan berguna untuk pelaksanaan pengelolaan rekam medis seperti:
a. formulir identitas pasien
b. formulir rawat jalan
c. Map rekam medis
d. rak rekam medis
e. softwer/ SIMRS
f. tracer, dan outget
g. buku pedoman rekam medis

Setelah peralatan tersebut diberikan kepada kedua klinik pratama, maka dilakukan perbaikan untuk formulir identitas pasien, formulir rawat jalan, Map rekam medis, rak rekam medis, Software/SIMRS, dan pemberian tracer dan outguet

Dari hasil perbaikan tersebut, pengelolaan rekam medis di dua klinik pratama sudah berjalan dengan baik sesuai dengan standar yang ditetapkan. Hal ini dapat dilihat dari perkembangan dalam pengelolaan rekam medis seperti dengan adanya bemberian tracer dan outguet dapat mempermudah tenaga rekam medis dalam menemukan berkas rekam medis yang diambil atau dipinjam.

Dengan diberikannya software/ SIMRS kepada kedua klinik dapat mempermudah petugas rekam medis dalam melakukan pendaftaran karena dalam sofware yang kami berikan telah menggunakan nomor antrian 
sehingga pasien dapat mengantri dengan tertib dan tidak perlu menunggu lama lagi seperti waktu melakukan pendaftaran secara manual sehingga mutu pelayanan yang diberikan semakin baik dan sesuai dengan standar pelayanan dan lama waktu penyediaan dokumen rekam medis rawat jalan menjadi cepat yaitu $\leq 10$ menit. Berikut hasil observasi lama waktu penyedian dokumen rekam medis rawat jalan di dua klinik pratama:

Tabel 1. Hasil observasi lama waktu penyedian dokumen rekam medis rawat jalan di dua klinik pratama

\begin{tabular}{|l|l|l|l|}
\hline No & Nama Klinik & Sebelum & Sesudah \\
\hline 1 & Klinik Indo Sehat & 14 Menit 20 detik & 10 Menit 02 detik \\
\hline 2 & Klinik Indo Sehat & 13 Menit 07 detik & 9 Menit 20 detik \\
\hline 3 & Klinik Indo Sehat & 12 Menit 31 detik & 9 Menit 30 detik \\
\hline 4 & Klinik Indo Sehat & 12 Menit 20 detik & 8 Menit 55 detik \\
\hline 5 & Klinik Indo Sehat & 13 Menit & 10 Menit \\
\hline 6 & Klinik Rumah Zakat & 13 Menit 11 detik & 10 Menit 10 detik \\
\hline 7 & Klinik Rumah Zakat & 14 Menit 22 detik & 10 Menit \\
\hline 8 & Klinik Rumah Zakat & 14 Menit 31 detik & 9 Menit 57 detik \\
\hline 9 & Klinik Rumah Zakat & 10 Menit 22 detik & 7 Menit 40 detik \\
\hline 10 & Klinik Rumah Zakat & 12 Menit 35 detik & 9 Menit 35 detik \\
\hline
\end{tabular}

\section{KESIMPULAN DAN SARAN}

Pengabdian IbMPerencanaan Pengelolaan Rekam Medis Sesuai Dengan Standar Pedoman Penyelenggaraan Dan Prosedur Rekam Medis Diklinik Pratama Kota Pekanbaru telah dapat dikerjakan dengan baik dan tanpa halangan yang berarti. Dengan kerja sama tim pengabdian yang baik dan peran aktif dari tenaga rekam medis dan mitra dalam kegiatan pengabdian ini maka semuanya telah berjalan dengan lancar sesuai dengan yang diharapkan. Harapan kami pengabdian ini dapat memberikan manfaat bagi kedua klinik pratama terutama petugas rekam medis.
Pengabdian yang kami lakukan ini telah selesai dilaksanakan sampai dengan tahapan pelaksanaan perbaikan formulir, map, rak, dan SIMRS. Pada tahap pengecekan formulir, map, rak, dan SIMRS yang pertama kami menemukan bahwa belum terdapatnya formulir untuk identitas pasien, formulir rawat jalan, map rekam medis dan rak rekam medis sudah ada namun belum sesuai standar dan Ketentuan DepKes, Serta SIMRS yang belum berjalan dengan baik. Kemudian kami memberikan formulir identitas pasien, formulir rawat jalan, Map, rak rekam medis, softwer, tracer, dan outget serta buku pedoman rekam medis untuk dipelajari lebih dalam oleh tenaga rekam medis. Setelah peralatan 
ISSN : 2550-0198

tersebut diberikan kepada kedua klinik pratama, maka dilakukan perbaikan untuk formulir identitas pasien, formulir rawat jalan, Map, rak rekam medis, dan SIMRS.

Pada akhirnya pengelolaan rekam medis di dua klinik pratama tersebut

sudah berjalan dengan baik dan sesuai dengan standar yang ditetapkan. Dengan diterapkannya pengelolaan rekam medis tersebut maka selesailah kegiatan pengabdian IbM Perencanaan Pengelolaan Rekam Medis Sesuai Dengan Standar Pedoman Penyelenggaraan Dan Prosedur Rekam Medis Diklinik Pratama Kota Pekanbaru.

\section{DAFTAR PUSTAKA}

[1] Depkes RI (2006). PedomanPenyelenggaraan dan Prosedur Rekam medis rumah sakit di Indonesia Revisi II,Dirjend. Bina Yanmed. Jakarta.--------,1997Pedoman

Penyelenggaraan Rekam

Medis, DirjendYanmed,Jakarta

[2] Normijani,Muhamad.(2013).Op timalisasi Pelaksanaan Rekam Medis di Rumah Sakit, Program Pascasarjana Univeristas Hasanudin.Makasar.

[3] Permenkes Republik Indonesia Nomor269/Menkes/Per/III/200 8 tentang Rekam Medis 